\title{
Application of Project Based Learning Models to Improve Student Learning Outcomes in Science Material
}

\author{
Yenny Anggraeni Pangkey \\ SD Margadana 5 Kota Tegal \\ yenianggraeni9911@gmail.com
}

\section{Article History}

accepted 01/11/2020

approved 08/11/2020

published 15/11/2020

\begin{abstract}
This study aims to determine the increase in learning outcomes in science learning through the application of the PjBL model. This research is a classroom action research with 21 students of grade VI SD Margadana 5 Tegal as the subject. This research was conducted in 3 cycles, each cycle of 2 meetings. Each meeting consists of 4 stages, namely planning, implementing, observing and reflecting. Based on the results of the research, in the first cycle, it was obtained an average of 68.09 classical student learning outcomes with $52 \%$ student completeness success, and in the second cycle the classical student learning outcomes were 70.47 with the completeness success increasing to $67 \%$ and still under the indicators of success. In cycle III, the classical average of student learning outcomes was 83.33 with the success of student completeness increasing to $86 \%$ in this case it was more than the $75 \%$ achievement indicator. So from cycle I, cycle II and cycle III there is an increase in student learning outcomes. So, in this study it can be concluded that using the PjBL model can improve student learning outcomes in science subjects magnetic and non-magnetic objects.
\end{abstract}

Keywords: learning outcomes, project based learning, science

\begin{abstract}
Abstrak
Penelitian ini bertujuan untuk mengetahui peningkatan hasil belajar dalam pembelajaran IPA melalui penerapan model PjBL. Penelitian ini merupakan penelitian tindakan kelas dengan subyek penelitian siswa kelas VI SD Margadana 5 Kota Tegal sebanyak 21 orang. Penelitian ini dilaksanakan 3 siklus, masing-masing siklus 2 kali pertemuan. Setiap pertemuan terdiri dari 4 tahap yaitu perencanaan, pelaksanaan, observasi dan refleksi. Berdasarkan hasil penelitian, pada siklus I diperoleh rata-rata hasil belajar siswa secara klasikal 68,09 dengan keberhasilan ketuntasan siswa $52 \%$, dan pada siklus II diperoleh rata-rata hasil belajar siswa secara klasikal 70,47 dengan keberhasilan ketuntasan meningkat menjadi $67 \%$ dan masih berada dibawah indikator keberhasilan. Pada siklus III diperoleh rata-rata klasikal hasil belajar siswa 83,33 dengan keberhasilan ketuntasan siswa meningkat menjadi $86 \%$ dalam hal ini sudah lebih dari indikator ketercapaian $75 \%$. Jadi dari siklus I, siklus II dan siklus III terjadi peningkatan hasil belajar siswa. Sehingga, dalam penelitian ini dapat disimpulkan bahwa dengan menggunakan model PjBL dapat meningkatkan hasil belajar siswa dalam mata pelajaran IPA materi benda magnetis dan non magnetis
\end{abstract}

Kata Kunci: Hasil Belajar, project based learning, IPA

Social, Humanities, and Education Studies (SHEs): Conference Series p-ISSN 2620-9284 https://jurnal.uns.ac.id/shes

e-ISSN 2620-9292 


\section{PENDAHULUAN}

Belajar adalah kegiatan yang berproses dan merupakan unsur yang sangat fundamental dalam penyelenggaraan setiap jenis dan jenjang pendidikan. Ini berarti bahwa berhasil atau gagalnya pencapaian tujuan pendidikan itu sangat tergantung pada proses belajar yang dialami oleh siswa. Terkait dengan upaya peningkatan kualitas belajar tersebut, salah satu yang harus dikembangkan oleh guru adalah bagaimana guru bisa menggunakan model pembelajaran dalam proses pembelajaran dengan sebaik-baiknya. Dengan kata lain, seorang guru harus bisa menerapkan model pembelajaran yang sesuai dan ideal dalam kegiatan belajar mengajar meskipun program sekolah sudah terencana dengan baik. Respon dan keaktifan siswa sangat kurang ketika mengerjakan tugas dan saat menjawab soal-soal evaluasi pada meteri benda magnetis dan non magnetis. Hal tersebut terjadi karena saat pembelajaran guru masih menggunakan model pembelajaran yang monoton dan cenderung membosankan. Siswa hanya diberi materi, berdiskusi dan penugasan. Sehingga hal tersebut berpengaruh terhadap hasil belajar siswa. Berdasarkan pengamatan awal yang dilakukan di SD Margadana 5 Kota Tegal, pada siswa kelas VI diperoleh nilai hasil belajar siswa pada pembelajaran IPA materi benda magnetis dan non magnetis tahun pelajaran 2020/2021 masih rendah. Dari hasil pengamatan diketahui bahwa dari jumlah keseluruhan siswa kelas $\mathrm{VI}$ sebanyak 21 siswa dengan KKM yang ditetapkan yaitu 70, hanya 5 siswa yang memperoleh nilai $\geq 70(24 \%)$ dan 16 siswa memperoleh nilai $\leq 70(76 \%)$. Berdasarkan permasalahan di atas, hasil pembelajaran IPA di SD Margadana 5 dikatakan kurang berhasil.

$\mathrm{Hal}$ ini menjadi tantangan bagi guru untuk tetap dapat menciptakan pembelajaran yang menyenangkan, menarik, aktif dan efektif yang nantinya akan berpengaruh terhadap peningkatan hasil belajar siswa yaitu dengan menggunakan model pembelajaran Project Based Learning. Pembelajaran berbasis proyek (Project Based Learning) adalah model pembelajaran yang menggunakan proyek sebagai inti pembelajaran (permendikbud, 2014:20 dalam Muchlisin Riadi Agustus 30, 2017 ) Model pembelajaran ini merupakan model pembelajaran inovatif yang melibatkan kerja proyek dimana peserta didik bekerja secara mandiri dalam mengkonstruksi pembelajarannya dan mengkulminasikannya dalam produk nyata (Nanang Hanafiah dan Cucu Suhana, 2009:30). Model pembelajaran Project Based Learning awalnya dikembangkan oleh The George Lucas Education Foundation dan Dopplet, dengan langkah-langkah pembelajaran berdasarkan beberapa fase sebagai berikut (Kemdikbud, 2014:34 dalam Muchlisin Riadi Agustus 30, 2017): Penentuan pertanyaan mendasar (start with essential question), Menyusun perencanaan proyek (design project), Menyusun jadwal (create schedule), Memantau siswa dan kemajuan proyek (monitoring the students and progress of project), Penilaian hasil (assess the outcome), Evaluasi Pengalaman (evaluation the experience).

Berdasarkan uraian diatas, tujuan dilakukannya penelitian ini antara lain : untuk mengetahuai upaya peningkatan hasil belajar IPA materi benda magnetis dan non magnetis dengan menerapkan model PjBL pada siswa kelas VI SD Margadana 5 Kota Tegal.

\section{METODE}

Metode penelitian yang digunakan dalam penelitian ini adalah penelitian tindakan kelas untuk meningkatkan hasil belajar siswa melalui penerapan model PjBL mata pelajaran IPA materi benda magnetis dan non magnetis. Data yang diperoleh kemudian dianalisis menggunakan analisis diskriptif komparatif yaitu membandingkan nilai tes evaluasi setelah siklus I, siklus II dan siklus III. Data kuantitatif dalam penelitian ini adalah evaluasi hasil belajar siswa. Setelah siswa mengerjakan soal dilakukan penskoran. Penskoran ini merupakan proses pengubahan jawaban-jawaban soal tes menjadi angkaangka. Angka-angka hasil penilaian tersebut selanjutnya diubah menjadi nilai-nilai untuk mengetahui gambaran yang jelas mengenai hasil belajar siswa dalam pembelajaran IPA

Penelitian ini dilakukan pada mata pelajaran IPA materi benda magnetis dan non magnetis. Subyek penelitian adalah siswa kelas VI SD Margadana 5 Kota Tegal yang melibatkan 21 siswa yang dilaksanakan pada bulan Oktober dan Nopember 2020. 
Instrumen pengumpulan data adalah tes evaluasi hasil belajar sedangkan teknis analisis data menggunakan teknik analisis deskriptif kualitatif menggunakan kreteria pencapaian ketuntasan dengan indikator ketercapaian $75 \%$.

\section{HASIL DAN PEMBAHASAN}

Dalam Penelitian Tindakan Kelas (PTK) ini menggunakan 3 siklus. Siklus aktivitas dalam PTK diawali dengan perencanaan tindakan (planning), penerapan tindakan (action), mengobservasi proses tindakan (observation), dan melakukan refleksi (reflection), dan seterusnya sampai perbaikan atau peningkatan yang diharapkan tercapai (kriteria keberhasilan). Pada penelitian ini rencana tindakan dalam 3 siklus dengan menggunakan model pembelajaran PjBL dan dalam satu pertemuan tersebut digunakan untuk evaluasi pembelajaran. Apabila proses pembelajaran pada siklus I belum mencapai hasil yang diharapkan maka peneliti akan melanjutkan ke tahap siklus berikutnya sampai hasil yang didapatkan tercapai dengan maksimal.

Pada siklus I persentase rata-rata hasil belajar siswa sebesar 68,09 dengan ketuntasan klasikal sebesar $52 \%$. Dalam hal ini taraf keberhasilan belajar siswa termasuk dalam kategori cukup baik. Dari hasil perbaikan pembelajaran yang telah dilaksanakan pada pembelajaran siklus I diperoleh hasil analisis pengamatan tes evaluasi pelaksanaan pembelajaran pada siklus I yang telah dilakukan yang tersaji pada tabel di bawah ini :

Tabel 1. Ketuntasan Klasikal Siklus I

\begin{tabular}{cccc}
\hline Nilai & Banyaknya Siswa & Persentase & Keterangan \\
\hline$<70$ & 10 & $48 \%$ & Tidak Tuntas \\
$\geq 70$ & 11 & $52 \%$ & Tuntas \\
\hline
\end{tabular}

Dari tabel di atas yaitu tabel ketuntasan hasil belajar siswa dapat diperjelas pada diagram di bawah ini:

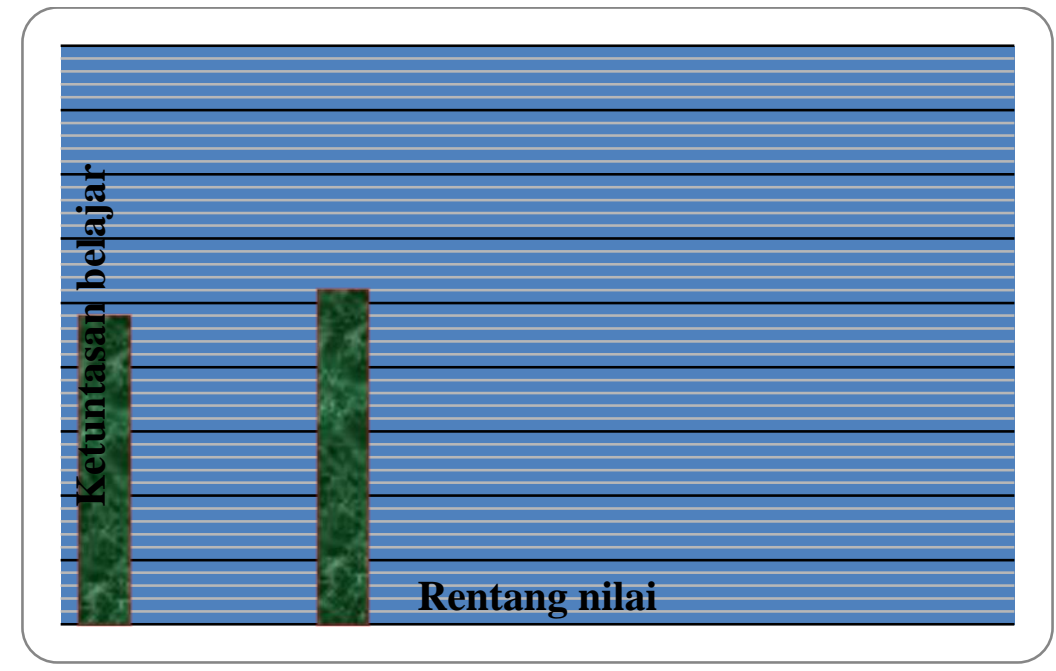

Gambar 1. Diagram Ketuntasan Klasikal Siklus I

Gambar diatas menunjukkan perbandingan persentase ketuntasan hasil belajar IPA siklus I. Siswa yang tuntas berjumlah 11 siswa atau $52 \%$ dari jumlah keseluruhan siswa dan siswa yang tidak tuntas berjumlah 10 siswa atau $48 \%$ dari jumlah keseluruhan siswa. Secara keseluruhan ketuntasan hasil belajar IPA pada siklus I, siswa yang mendapat nilai di atas KKM 70 masih kurang dari persentase $75 \%$ dari jumlah keseluruhan siswa.

Keterlaksanaan model PjBL pada siklus I terpenuhi tiga dari enam langkah. Dalam hal ini taraf keberhasilan belajar siswa termasuk dalam kategori cukup. Dari hasil perbaikan pembelajaran yang telah dilaksanakan pada siklus II, diperoleh hasil nilai evaluasi belajar yang tersaji pada tabel 2 di bawah ini: 
SHEs: Conference Series 3 (3) (2020) 531- 537

Tabel 2. Ketuntasan Klasikal Siklus II

\begin{tabular}{cccc}
\hline Nilai & Banyaknya Siswa & Persentase & Keterangan \\
\hline$<70$ & 7 & $33 \%$ & Tidak Tuntas \\
$\geq 70$ & 14 & $67 \%$ & Tuntas \\
\hline
\end{tabular}

Dari tabel di atas yaitu tabel ketuntasan hasil belajar siswa dapat diperjelas pada diagram di bawah ini:

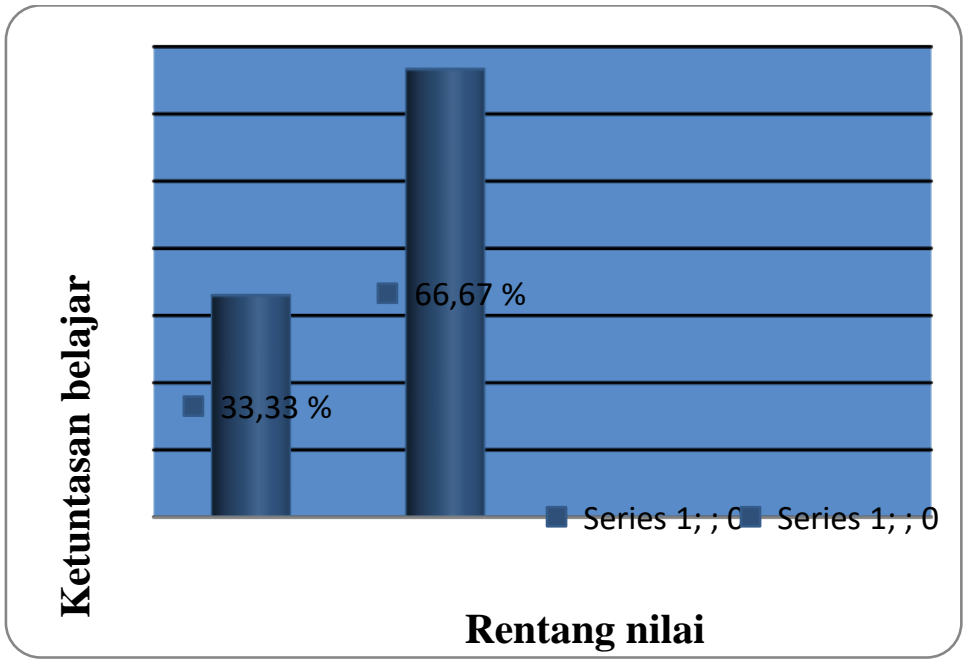

Gambar 2 Diagram Ketuntasan Klasikal Siklus II

Gambar di atas menunjukkan perbandingan persentase ketuntasan hasil belajar IPA siklus II. Siswa yang tuntas berjumlah 14 siswa atau $67 \%$ dari jumlah keseluruhan siswa dan siswa yang tidak tuntas berjumlah 7 siswa atau $33 \%$ dari jumlah keseluruhan siswa. Dari hasil data siklus II tersebut menunjukkan peningkatan keberhasilan belajar siswa, akan tetapi jumlah prosentase ketuntasan masih berada dibawah indikator keberhasilan sebesar $75 \%$ Sehingga peneliti perlu melanjutkan tindakan penelitian ini sampai pada siklus III.

Dari hasil perbaikan pembelajaran yang telah dilaksanakan pada siklus III, diperoleh hasil nilai evaluasi belajar yang tersaji pada tabel 3 di bawah ini:

Tabel 3 Ketuntasan Klasikal Siklus III

\begin{tabular}{llll}
\hline Nilai & Banyaknya Siswa & Persentase & Keterangan \\
\hline$<70$ & 3 & $14 \%$ & Tidak Tuntas \\
$\geq 70$ & 18 & $86 \%$ & Tuntas \\
\hline
\end{tabular}

Dari tabel di atas yaitu tabel ketuntasan hasil belajar siswa dapat diperjelas pada diagram di bawah ini: 
SHEs: Conference Series 3 (3) (2020) 531- 537

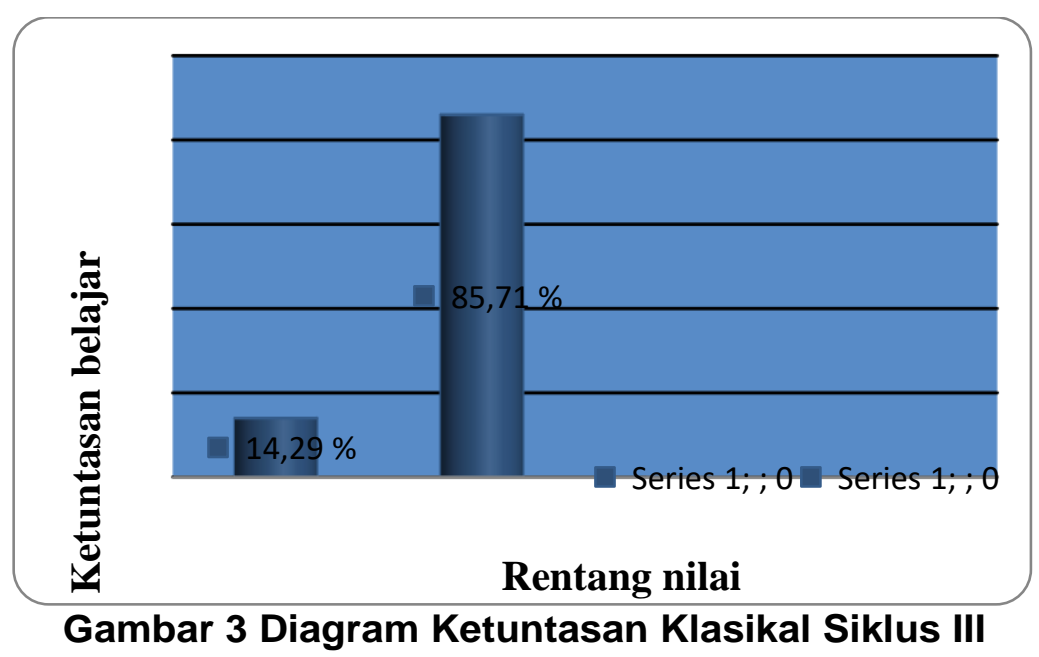

Gambar diatas menunjukkan perbandingan persentase ketuntasan hasil belajar IPA siklus III. Siswa yang tuntas berjumlah 18 siswa atau $86 \%$ dari jumlah keseluruhan siswa dan siswa yang tidak tuntas berjumlah 3 siswa atau $14 \%$ dari jumlah keseluruhan siswa. Dari hasil data siklus III tersebut menunjukkan peningkatan keberhasilan belajar siswa, Berdasarkan nilai Kriteria Ketuntasan Minimal (KKM) mata pelajaran IPA yaitu 70 telah tercapai pada siklus III dan telah memenuhi indikator capaian keberhasilan penelitian sebesar $75 \%$. Sehingga peneliti mengakhiri tindakan penelitian ini sampai siklus pada III.

Penerapan model PjBL dapat meningkatkan hasil belajar belajar IPA. Hasil evaluasi pembelajaran dari setiap pembelajaran yang dilakukan selalu mengalami peningkatan. Sebelum menggunakan model pembelajaran PjBL persentase ketuntasan hanya sebesar $24 \%$. Pembelajaran siklus I dengan menerapkan model PjBL keberhasilan ketuntasan mengalami peningkatan dengan menjadi $52 \%$. Pada pembelajaran siklus II dengan menerapkan model PjBL mengalami peningkatan dengan persentase keberhasilan ketuntasan sebesar 67\%. Pada siklus III dengan menerapkan model PjBL prosentase ketuntasan meningkat menjadi 86\% diatas indikator keberhasilan $70 \%$. Peningkatan nilai rata-rata siswa dari pra siklus 52,33 menjadi 68,09 pada siklus I. Pada siklus II nilai rata-rata siswa 70,47 dan meningkat menjadi 83,33 pada siklus III.

Hasil belajar peserta didik digunakan untuk mengetahui sejauh mana pemahaman peserta didik terhadap materi pembelajaran yang dinyatakan dalam bentuk nilai. Menurut Nawawi (dalam kutipan Ahmad Susanto) menyatakan bahwa hasil belajar dapat diartikan sebagai tingkat keberhasilan siswa dalam mempelajari materi pelajaran di sekolah yang dinyatakan dalam skor yang diperoleh dari hasil tes mengenal sejumlah materi pelajaran tertentu. Adapun menurut Winkel (dalam kutipan Purwanto), hasil belajar adalah perubahan yang mengakibatkan manusia berubah dalam sikap dan tingkah lakunya. Dengan demikian peserta didik yang telah melalui evaluasi pembelajaran berarti guru berupaya memperbaiki kekurangan dari hasil yang diperoleh peserta didik.

\section{SIMPULAN}

Peneliti telah menerapkan model pembelajaran Project Based Learning dalam melaksanakan pembelajaran pelajaran IPA pada materi Benda magnetis dan non magnetis di kelas VI SD Margadana 5 Kota Tegal. Berdasarkan analisis data yang diperoleh dari hasil pelaksanaan siklus I, II, dan II, dapat ditarik simpulan bahwa penerapan model PjBL dapat meningkatkan hasil belajar siswa kelas VI SD Margadana 5 Kota Tegal. Peningkatan pada hasil belajar yang telah dicapai tersebut dapat disimpulkan sebagai berikut: Hasil belajar siswa, nilai hasil belajar yang diperoleh pada siklus I, rataratanya sebesar 68,09, sedangkan pada siklus II mengalami peningkatan mencapai 
70,47 , kemudian pada siklus III mengalami peningkatan lagi sebesar 83,33 . Meningkatnya rata-rata nilai hasil tes evaluasi pada siklus II dan III menjadikan persentase ketuntasan belajar juga ikut meningkat. Pada siklus I, persentase ketuntasan belajar yang diperoleh hanya sebesar $52 \%$, sedangkan pada siklus II, presentase ketuntasan belajar sebesar $67 \%$, kemudian pada siklus III persentase ketuntasan meningkat menjadi $86 \%$. Ini berarti hasil belajar IPA pada materi benda magnetis dan non magnetis peserta didik kelasVI SDN Margadana 5 Kota Tegal dengan menggunakan model PjBL meningkat.

\section{DAFTAR PUSTAKA}

(yogapermanawijaya.wordpress.com/2014/11/16/project-based-learning-pjbl-problembased-learning-pbl/)

Riadi, Muchlisin. (2017). Model Pembelajaran berbasis proyek.diakses pada tanggal 13 Oktober 2020 pukul 20.45 pada https://www.kajianpustaka.com/2017/08/modelpembelajaran-berbasis-proyek.html

Priambodo, Iwan.2014. Jurnal PTK. Diakses pada tanggal 13 Oktober pada www.academia.edu/11498848/jurnal PTK

Arikunto, S. Suhardjono, dan Supardi. (2008). Penelitian Tindakan Kelas. Jakarta: Bumi Aksara.

Undang-Undang RI Pasal 1 ayat 1 Nomor 20 Tahun 2003 tentang Sistem Pendidikan Nasional.

Aunurrahman. 2009. Belajar dan Pembelajaran. Bandung: Alfabeta.

Djamarah, Syaiful Bahri. 2008. Psikologi Belajar. Jakarta: Rineka Cipta.

Winataputra, Udin S. dkk. 2008. Teori Belajar dan Pembelajaran. Jakarta: Universitas Terbuka.

Anitah W., Sri Dkk. 2014. Strategi Pembelajaran Di SD. Jakarta: Universitas Terbuka Departemen Pendidikan Nasional.

Surakhmad, Winarno. 1979. Metodologi Pengajaran Nasional. Bandung: Jemmars.

Sumantri, Mulyani. 2013. Perkembangan Peserta Didik. Jakarta: Universitas Terbuka Departemen Pendidikan Nasional.

Sapriati, Amalia., dkk. 2014. Pembelajaran IPA di SD. Jakarta: Universitas Terbuka Departemen Pendidikan Nasional.

Arikunto, Suharsimi. dkk. 2010. Penelitian Tindakan Kelas. Jakarta: Bumi Aksara.

Aqib, Zainal dkk. 2010. Penelitian Tindakan Kelas. Bandung: Yrama Widya.

BSNP. 2007. Pedoman Penilaian Hasil Belajar di Sekolah. Jakarta: Departemen Pendidikan Nasional Direktorat Jenderal Mandikdasmen Direktorat Pembinaan TK dan SD.

Puerwadarminta. 2003. Kamus Umum Bahasa Indonesia. Jakarta: PN Balai Pustaka.

Hamalik, Oemar. 2011. Proses Belajar Mengajar. Jakarta: Bumi Aksara. 
Anggari, Angga St dkk. 2018. Tema 5 Wirausaha. Jakarta: Kementrian Pendidikan dan Kebudayaan (halaman: 63-75).

Saptorini, Dhiah dkk. 2018. Wirausaha. Jakarta: Yudhistira (halaman: 43-51) 